\title{
WRITING OUT, READING IN: THE POETIC PERSONA ON YOUNG BLOGGING WRITERS
}

\author{
Laura de la Parra Fernández*
}

\begin{abstract}
In this paper I analyse the work by young blogging North American writers, whose presence on the Internet shapes and defines the main features of their literature. As a main difference regarding traditional literature, what stands out is the effect that the exposure of an "Internet poetic persona" as well as a confessional-narcissistic tone creates on the reader. Since Internet behaviour can also be read as part of a performance, the reader constructs the text taking into account all the data surrounding the author such as participation in social networks. Author-reader interaction is a key point even before the publishing market enters the scene and mediates between the two. Thus, the reader is more involved and active in the writing and publishing process than ever.
\end{abstract}

KEY WORDS: Poetry. Internet. Blog. Social networks.

In her short essay Poetry Is Not a Project (Ugly Duckling Presse, 2010), American poet Dorothea Lasky (born in 1978) defends the idea that poetry should not be something studied and premeditated, but rather something spontaneous, experience-based, nonlinear, unintentional, and which can only be defined by the mere experience of a poem. Despite being a bit older than her peers, this text could be seen as the manifesto for an incipient generation of blogging writers where the text runs parallel to life and ends always in the poet-they become the poem.

Lasky, who has published three poetry collections on the prestigious Awe Books plus the aforementioned essay (available in PDF format in the webpage of the publishing house since it became out-of-print $)^{1}$, is a bit different from her younger counterparts. She does have a blog (<www.birdinsnow.com $>$ ) but she keeps it more as an archive of news about her new publications and appearances in journals and magazines, as most authors born before the 1980s do. The most remarkable difference for this upcoming generation of

\footnotetext{
*Universidad Complutense de Madrid. snowfragance@gmail.com

${ }^{1}$ LASKY, Dorothea. Poetry Is Not A Project. Brooklyn: Ugly Duckling Presse, 2010. Available in: $<$ http://www.uglyducklingpresse.org/catalog/online-reading/poetry-is-not-a-project-by-dorothealasky/>.
} 
writers is that they blog before they publish. In fact, their blogs constitute their main body of literature, their publications being additional or a reaffirmation of the former, but never the opposite.

The main difference between a blog and a book lies in the fact that a blog is continually updated and open (in most cases) to others' commentaries. The blog is not used solely as a book, diary, newsletter or notebook, but rather as a mixture of the three and none of them at the same time. In fact, these blogs usually offer an account of a real and/or fictional daily life in a somewhat 'literary form' (if we understand by 'literary' the use of 'special' or 'not everyday language'), accompanied by pictures, quotes from other authors, book reviews, etc. In fact, the main characteristic of these blogs is that they revolve around the "I" as subject and object of the literary matter. Therefore, the published work arises from the author's blog and completes it, and not the other way round, as it happens in writers from previous generations. Thus, the poet, or rather, the poetic persona created on the net -not only on the author's personal blog, but through the use of other social networks, such as Facebook, Twitter, Formspring, etc.-, embodies the work itself. I will mainly refer to poetry from now on because this is the genre the texts I will refer to receive, mostly because of having a poetic "l" as a subject and expressing emotions and subjectivity.

The group of poets we will be looking at range from ages 18 to 28 , they come from different parts of the United States and most of them have started or completed undergraduate education. They all have a blog and are familiar with social networks from a young age. Most of them are also active on Facebook, Twitter or others (such as Formspring, a platform were Internet users can ask questions to the owner of the profile, everyone being able to become an interviewer and an interviewee), and their works also appear in digital literary magazines such as Metazen or Pop Serial. They are, thus, digital natives who have grown up sharing their work with their peers, creating their own literary magazines and exploring the world of literature through sharing of knowledge online. Their role as writers is as important as their role as readers, especially among their group, since due to living in different locations far from each other, their main communication has developed through the Internet. This might be 
the reason why, despite having different interests and personalities, their texts all share a series of identifiable characteristics. I have drawn my analysis from Young (2010), although his is more focused on thoroughly examining technical details and mine puts together form and content.

The first and main characteristic we find is self-centeredness ("Extreme (ironic) egotism", Young). The theme of the poem revolves around the experience, thought and feeling of the poetic "I", usually identified with the writer through the use of a confessional tone or sometimes even using the name (especially in epistolary series of poems between two writers). For example, in this excerpt from "you know nothing about love darling" (2010) by Kendra Grant Malone (1984) we find an apparently simple anecdote between the poetic "l" and her partner used to illustrate the clash of wills.

\author{
it was halloween \\ and i drank too much champagne \\ we had just started dating \\ i fell in a mosh pit \\ and got my face stepped on \\ i was wearing leopard pants \\ and a vest that said man eater \\ i wanted to bike home \\ but you would not let me \\ i was so very angry at you \\ for making me walk
}

The confessional, embarrassed tone is also recurrent, as in this excerpt from Ana Carrete's make-believe love-making, a self-published chapbook that sold out through her blog.

my stomach growls

when you kiss me, and it's embarrassing.

The experiences portrayed usually convey the expression of numbness, depression and boredom towards the real world, impossibility to connect with 
others and apparent lack of emotion, reflected in the dryness of the literary language as well. Poems are more narrative than lyric, with reference to the common, everyday world, rather than to metaphysical ideas, i.e.: food, brands and technology (especially the Internet as a means of social interaction), as we can see in these poems by Ana Carrete (1985) from Pop Serial (ISSUE 3, 2012):

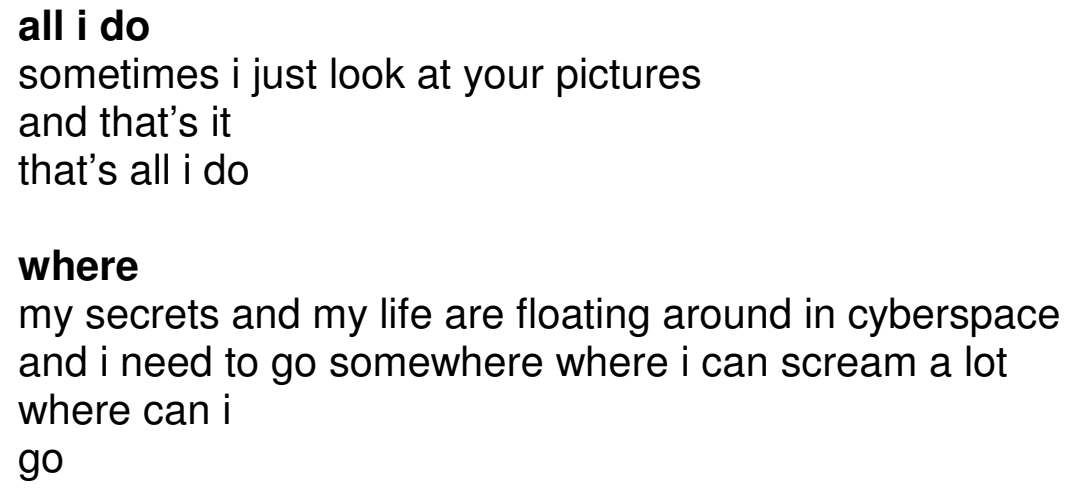

We can also observe that the poems have some characteristics of automatic writing based on the immediacy of chats and social networks: use of lower-case letters, no punctuation marks unless the writer wants to emphasize something. There is an anecdotal tone, a succession of events with little or no apparent connection that lead the protagonist to a series of thoughts about his or her way of relating with the world.

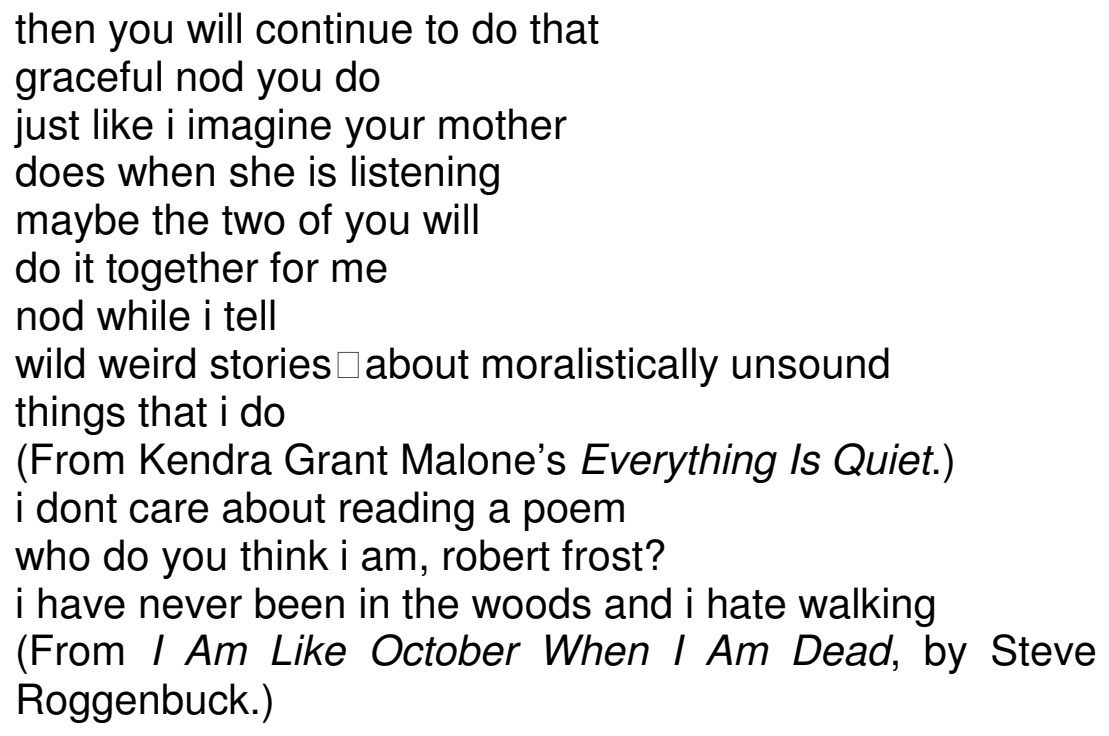


There is also a lack of climax or "restoration" in endings. Young adds "ending a poem with a question" and "Ending with an end (e.g., fade to black, death, credits, Fin)". For instance, in the poem "Orange", from Ellen Kennedy's Sometimes My Heart Pushes My Ribs (Muumuu House, 2010), the poem only expresses a wish of the poetic I, but there is no denouement or catharsis; the poet is just fulfilled by the depiction of that scene.

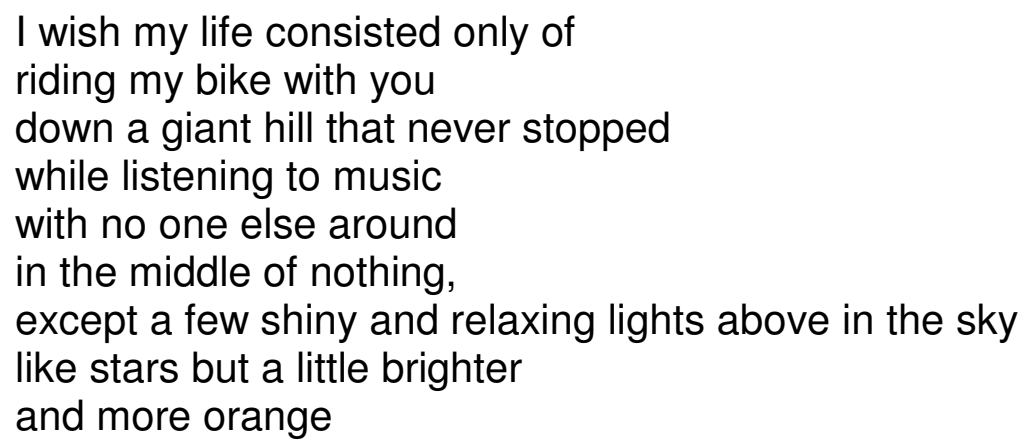

Genres are blurred: poetry, fiction, essay, lists and personal accounts are all put together at times and interconnected at others, as many of the usual partly essay, partly personal memoir on Thought Catalogue, a non-fiction site selfdescribed as "supporting the future of journalism"2. However, it has also been criticised for promoting voyeurism and "bluntly simplified, highly emotionalized life advice" (NEWTON, 2012). See, for instance, Megan Boyle's "Everyone l've Had Sex With" (2010).

Performativity and the use of new technologies are also present through video recordings of readings, pictures, or Photoshop-based drawings. e.g.: Richard Chiem and Ana Carrete's Oh No Everything Is Wet Now (Magic Helicopter Press, online). This is another example of collective authorship, usually with no more than two people in a kind of dialogue (question-answer texts). Others examples are Hikkimori by Ellen Kennedy and Tao Lin (Bear Parade, 2007, online) or Morocco by Matthew Savocca and Kendra Grant Malone (Dark Sky Books, 2012).

\footnotetext{
${ }^{2}$ Thought Catalog: About. Available in: $<$ http://thoughtcatalog.com/about/>.
} 
Internet is the means that bounds together this incipient generation, of which a remarkable, iconic example is the polemical writer Tao Lin (1983), owner of a small publishing house, Muumuu House, and a film company, MDMAfilms. Lin has more than 10.000 followers on Twitter, and sold his upcoming novel to Random House before it had been written. He enacts the performativity of his writing in so far as he is often online retransmitting live everything he does, and he even recorded himself when he married poet Megan Boyle in Las Vegas. In fact, his literature describes a world of bored young adults with money, technological devices connected $24 / 7$ to the Internet, but who are unable to communicate and thus, write about it. Ex-wife Megan Boyle writes a blog and has written some pieces of self-confessional literature/essays for Thought Catalogue with titles such as "Everyone l've Had Sex With", "Everyone I've Fallen In Love With", "Lies I've Told" or "Five Most Memorable Binge-Eating Experiences". Boyle also recently published a collection of poetry/thoughts, selected unpublished blog post of mexican panda express employee, in Tao Lin's publishing house, in whose webpage we can read:

\begin{abstract}
Muumuu House (est. 2008) is a publisher of poetry, fiction, Twitter selections, Gmail chats online \& in print. Content is published online every 2 to 60 days. Books [hyperlink] are published every .2 to 3 years \& can be purchased in the store [hyperlink]. Muumuu House does not accept submissions for acceptance or rejection. All its content was first read on blogs, in books, on Twitter, or elsewhere on the internet. ${ }^{3}$
\end{abstract}

That is, the contents published are strictly constricted to the fact that they have been read (despite the ironic title of Boyle's book), in contrast with the traditional publishing rule that the content should be previously unpublished.

However, the authors above are best known as "Internet celebrities" or "alternate celebrities", with thousands of online users peeking into their lives through their texts. The success of this confessional literature may as well be related with the success of social networks worldwide, and this with exhibitionistic-voyeuristic tendencies that underlie them: we want to know more

\footnotetext{
${ }^{3}$ Source: Muumuu House. Available in: <http://muumuuhouse.com/about.html>.
} 
about others, we want others to know more about us, but we want to do it without getting too involved with people. In the moment the event appears publicly on the screen in the form of text or images, it becomes less of an event and more of a representation of it. Hence the reader is able to approach it from an aesthetic point of view and enjoy it as one enjoys the performance of a play. The same happens to the author: in the moment he makes public something private, it is more of a performance and a representation, it becomes art because it is enacted and portrayed within a narrative, that is, it has a specific means and recipient, even though this is supposed to be "non-existent" since the content is written as though nobody is going to read it, but it is done so intentionally. Therefore, there is an audience: the voyeur, and the work has to be interesting enough so that it keeps the reader's attention.

Another striking case is that of Marie Calloway, a pseudonym for a young writer who suddenly gained haters and admirers after publishing a supposedly autobiographical 15.000-word story, "Adrien Brody", in Muumuu House, and a second one in Vice Magazine ${ }^{4}$. The event was even reviewed by The New York Observer, but most comments she received on the web had little or nothing to do with the text, but rather with her self and the collateral damage her writing may have caused to the people related to the story (cfr. Gay, 2011). For instance, the Observer's headline read: "Meet Marie Calloway: The New Model for Literary Seductress is Part Feminist, Part 'Famewhore' and All Pseudonymous" 5 . This phenomenon is not new; in fact, sixteen-year old student Cory Kennedy became a celebrity thanks to just posting pictures of herself on her blog. Now, with the help of the Internet, the "celebrity culture" and mythologization that started in Western countries at the beginning of the $20^{\text {th }}$ century thanks to Hollywood has developed to a point where everyone can become a celebrity on his own, and the literary world does not escape from that in so far as it is now the author the one who has to act as literary agent, publicist and even editor before being published by a company (and sometimes

\footnotetext{
${ }^{4}$ Vice Magazine is considered to be the most mainstream (and most followed) of alternative magazines. Available in: <http://www.vice.com/>.

${ }^{5}$ STOEFFEL, Kat. Meet Marie Calloway: The New Model for Literary Seductress is Part Feminist, Part 'Famewhore' and All Pseudonymous. The New York Observer. December 20 2012. Available in: <http://observer.com/2011/12/20/meet-marie-calloway/>.
} 
even so). Thus, authors become their own "trademark" which they have to sell, mostly through the social networks, as a product: they not only sell their work, but also themselves as an embodiment of the work. An example of this is the website "Alt Lit Gossip", about rumours and gossip from the authors on the independent literary scene ${ }^{6}$.

However, in the United States, the tradition of literary magazines is still maintained, although they have now become mostly online journals of varying range of topics and extension: from the more general but prestigious HTMLGIANT and its British counterpart 3AM Magazine, to the alternativeliterature journal Metazen or the popular collection of random thoughts Thought Catalogue, to the hundreds of small themed magazines such as red light bulbs or the democratic New Wave Vomit owned by poet Ana Carrete where the front page reads "vomit: anything you need to let out" and each writer is presented in a separate page ${ }^{7}$.

Indeed, the Internet allows for democratization and a wider choice of texts to read. Among these blogging writers the trend is to self-publish their own chapbooks online (although online publishing houses are beginning to arise as well) or self-publish them in paper and sell them through online contact and methods such as PayPal (for instance, Ana Carrete's self-published makebelieve love-making). In fact it seems that even though the Internet offers endless possibilities especially regarding the reach of the text, we still long for paper. The work on paper complements both the blog and its author-persona inhabiting the social networks, but it certainly adds to them some kind of covert prestige. Many of them attract independent publishers such as The Scrambler Books, Dark Sky Books or Civil Coping Mechanisms, but up until now only a few have attracted the bigger publishers (Tao Lin or Dorothea Lasky).

The web allows for interaction, while a printed book does not. Usually other users are allowed to leave comments and responses to the blog posts, even sometimes answering a poem with another poem, creating a web of links. As

\footnotetext{
${ }^{6}$ Alt Lit Gossip. Available in: <http://www.altlitgossip.com/>.

${ }^{7}$ New Wave Vomit. Available in: <http://newwavevomit.com/>.
} 
Regueiro (in press) underlines regarding concerns with quantity and quality, it is the reader the one who acts like a filter in the end. However, given that you may or may not identify yourself in the comments' section, an over-emphatic admiration can appear as well as the well-known phenomenon of "trolling", that is, a derogatory criticism that has actually nothing to do with the quality of the text itself or it is not well argued, but which is only there to provoke an enraged response. The arising of the poetic "persona" enacted by the poet all over the net makes it an easy target for the "trolls" or simple gossipers to make up adhominem arguments to use against them.

With the spread use of the Internet worldwide, subjectivity is now the more than popular standpoint, and this is reflected in literature as well. However, does this subjectivity mean that texts should be read as autobiographical, or in case they are, does it affect the reading? And how? Are we reading just the texts or also the inextricable web that surrounds them, given that everything is connected on the net? Lasky (2010) argues that poetry should be "regarded as life", not as intention but as "a human instinct" (LASKY, 2010, p. 18). Besides, even if the accounts by Boyle (2010) or Carrete in "The first time I was 'someone else' online" (2012) might as well be true-which seems to be supported by the detailed data, the pictures of themselves accompanying the texts, and their Internet personas on Facebook, Twitter, etc-, many studies show that people lie about themselves on the Internet, so writers may do it even more, writing out their Internet personas as part of their work. For instance, British author Ben Brooks recollects his evenings out with friends in a literary way, but using also pictures, as a teenager blogging about his life would do. In this case, he is also keen on tattooing words on himself, which remarks even more the image of the body being part of the text. Brooks' blogging, who published his first novel Grow Up in Penguin in 2011, resembles more the "Do It Yourself" approach of American peer writers than other British young poets, for less blogs by young British authors can be found. In fact, nowadays the best well-known British young authors are the ones awarded with the Faber New Poets Prize, which encompasses tradition and innovation, and a year of training in order to publish 
a chapbook ${ }^{8}$, and independent press does not seem to flourish yet in Britain. Whereas in America, the predominant approach is the one that Lasky summarizes in her essay: "Poetry is not the project of the poet-it is the very life of the poet" (LASKY, 2010, p. 21). Therefore, is it relevant for the Internet reader to approach the poet's life as part of his work or can it be read separately? And whose subjectivity predominates: that of the reader or that of the writer?

The fact that contents are accessible and debatable at almost real time means that author, text and reader are more entangled and inseparable than ever. As an example, Megan Boyle answered a review to her book in her blog in "real time", that is, writing in stream-of-consciousness style at the same time she was reading the review ${ }^{9}$, to which more people could leave comments, and so on. This not only shows the importance of the reader what the reader makes of this experience-texts before the publishing process, but also after, conceiving the book not as a closed object but as an open one, enabling discussion and insights both from the reader and the author, perhaps even attracting more readers than before. In fact, despite being a type of confessional literature that enacts personal experience and individuality (perhaps due to the apparent lack of taboos or previous taboos in our time), it requires more than ever the reaction of the reader to sustain this textual intimacy.

Thus, despite the apparent narcissistic nature that we found as a main characteristic of those texts, the reader plays an important part, embodying the experience of the text and giving life to that poetic persona, by constructing it after the writer's traces. Years to come and more research will show how this new approach to reading and writing is transforming the production of texts in different mediums. We will also see whether the phenomenon will spread and how to other countries (and if so, which and how), or if paper and the editorial filter will keep maintaining privilege as they now seem to do. This will affect our

\footnotetext{
${ }^{8}$ More information about the Faber New Poets available in: <http://www.faber.co.uk/list/fabernew-poets/>.

${ }^{9}$ BOYLE, Megan. "after rachel hyman's 'after megan boyle's 'selected unpublished blog posts of a Mexican panda express employee'". March 25 2012. Available in: $<$ http://tomhankssuperfan.blogspot.com/2012/03/i-reviewed-rachel-hymans-review-of-my.html>.
} 
use and approach to literature, genre and the technological media, breaking the boundaries between a professional and amateur author. They might be based on something else than authorial intention, market figures or popularity. Communication, perhaps.

\section{Works Cited}

BOYLE, Megan. Everyone I've Had Sex With. In: Thought Catalogue. October 9 2010. Available in <http://thoughtcatalog.com/2010/everyone-sex-list-peoplehumans/>. Access in May 162012.

CARRETE, Ana. 6 Poems. In: Pop Serial. Issue 3. April 2012. Available in <http://issue3.popserial.net/ana-carrete/>. Access in May 152012.

. The first time I was 'someone else' online. In: Bulk Culture. May 152012. Available in <http://bulkculture.com/the-first-time-i-was-someone-else-online/>. Access in May 162012.

GAY, Roxanne. The Price of Revelation. In: HTMLGIANT. December 232011. Available in <http://htmlgiant.com/web-hype/the-price-of-revelation/>. Access in May 162012.

LASKY, Dorothea. Poetry Is Not A Project. Brooklyn: Ugly Duckling Presse, 2010. Available in <http://www.uglyducklingpresse.org/catalog/onlinereading/poetry-is-not-a-project-by-dorothea-lasky/>. Access in May 152012.

NEWTON, Matthew. Thought Catalog and the New Age of Confessional Media. In: Forbes. Available in: $<$ http://www.forbes.com/sites/matthewnewton/2012/02/08/thought-catalog-andthe-new-age-of-confessional-media/>. Access in May 262012.

REGUEIRO, Begoña. Un nuevo cauce para la comunicación literaria: los blogs en manos de los escritores. In: GOICOECHEA, M; GARCÍA, Pilar. (Eds.) Alicia a través de la pantalla. Madrid: CITA, Fundación Germán Sánchez Ruipérez.

YOUNG, Mike. Moves in Contemporary Poetry. In: HTMLGIANT. January 12 2010. Available in <http://htmlgiant.com/craft-notes/moves-in-contemporarypoetry/>. Access in May 142012.

Texto recebido em 19/06/2012 